\title{
PERBANDINGAN KONSEP PERSALAMAN “TERIMA KASIH" DALAM BAHASA INDONESIA DAN BAHASA JEPANG
}

\author{
Elizabeth Ika Hesti Aprilia Nindia Rini \\ Universitas Diponegoro \\ (eliz_ikahesti@yahoo.co.id)
}

\begin{abstract}
Greetings is necessary in human relationship. If we can't express greeting properly we will be regarded as the less civilized. And not to know how to use expressions that show gratitude can lead us to misunderstandings that would be not good for the relationship that has been existed. Indonesian expressed gratitude by using idiomatic expressions such as"terima kasih", "makasih", "trims" with sincerity, meanwhile Japanese expressed kansha (gratitude) using standard existing idiomatic expressions such as "arigatou gozaimasu", "sumimasen”, "doumo", etc, describing the facts that occurred, describing the feeling of the speaker, and gestures.
\end{abstract}

Kata Kunci : greetings, gratitude, terima kasih,arigatou gozaimasu

\section{PENDAHULUAN}

Interaksi dilakukan manusia untuk berbagi perasaan, pengalaman dan pengetahuan, mengembangkan potensi, serta mendapatkan bantuan yang diperlukan dalam kehidupannya. Sebagai makhluk sosial, manusia memiliki kebutuhan untuk berinteraksi dengan sesamanya.

Bentuk komunikasi sederhana yang kerap dijumpai dalam interaksi sosial adalah salam atau persalaman. Menurut wikipedia,

"Salam merupakan cara bagi seseorang (juga binatang) untuk secara sengaja mengkomunikasikan kesadaran akan kehadiran orang lain, untuk menunjukkan perhatian, dan / atau untuk menegaskan atau menyarankan jenis hubungan atau status sosial antar individu atau kelompok orang yang berhubungan satu sama lain". (//id.wikipedia.org)

Sementara itu menurut KBBI dalam jaringan, salam berarti damai; pernyataan hormat; atau ucapan assalamu alaikum warahmatullahi wabarakatuh; sedangkan persalaman berarti hal-hal yang berhubungan dengan pemberian salam.

Sejalan dengan itu, menurut "Infoword Kokugojiten", aisatsu atau salam adalah,

1) Hito to attari wakaretari suru toki no kawasu kotoba.
2) Kaigoude no shukuji/shaji nado.

(Shimazaki Youichi dkk, 1999 : 2) yang berarti bahwa salam adalah kata yang dipertukarkan pada saat bertemu atau berpisah dengan seseorang; misalnya ucapan terima kasih atau ucapan selamat, dan lain-lain.

Dari uraian di atas disimpulkan bahwa persalaman merupakan wujud komunikasi yang saling dipertukarkan untuk menunjukkan perhatian akan kehadiran orang lain dalam bentuk verbal maupun non verbal.

Tata cara persalaman dipengaruhi oleh budaya tempat masyarakat itu tinggal dan diekspresikan melalui ucapan, gerakan, atau gabungan dari keduanya. Dalam bahasa Indonesia misalnya, persalaman terealisasi dalam ucapan sebagai berikut,

1. "Hai" atau "Halo" (sapaan saat bertemu.)

2. "Apa kabar?", "Bagaimana kabarnya?", "Semoga lekas sembuh" (ungkapan perhatian terhadap kondisi seseorang.)

3. "Selamat pagi", "Selamat siang", "Selamat sore", atau "Selamat malam" (ucapan selamat yang berkaitan dengan waktu dalam satu hari.)

4. "Selamat ulang tahun", "Selamat hari raya", "Selamat datang", "Selamat tinggal", "Selamat jalan", "Selamat 
wisuda" (ucapan selamat yang berkaitan dengan peristiwa tertentu.)

5. "Assalamu alaikum" (Islam), "Shalom" (Kristen), "Om Swastiastu" (Hindu) (salam yang berkaitan dengan agama dan kepercayaan.)

Selain itu ada pula ungkapan salam yang disampaikan melalui gesture yang kerap dilakukan oleh orang Indonesia misalnya, berjabat tangan atau bersalaman, mengangguk, membungkuk, mencium tangan, mencium pipi, atau melambaikan tangan.

Bila dilihat dari fungsinya, salam merupakan salah satu sarana untuk menjaga agar hubungan antarmanusia berjalan dengan baik.

Bagi orang Indonesia salam ditujukan untuk menunjukkan perhatian, sedangkan bagi orang Jepang salam tidak ditujukan untuk membuat hubungan yang baru, melainkan untuk menjaga hubungan yang sudah ada tetap baik atau bisa dikatakan tidak lebih dari sarana untuk saling memastikan bahwa hubungan yang terjalin tetap seperti semula dan tidak berubah menjadi musuh.

Pemahaman akan persalaman merupakan langkah awal untuk memahami budaya dan membangun relasi lebih lanjut dengan seseorang yang bahasanya sedang dipelajari, sehingga dapat menggunakannya secara tepat.

Dalam hal ini penulis tertarik untuk mengkaji perbedaan antara persalaman terima kasih dalam bahasa Indonesia dan bahasa Jepang.

Pengungkapan persalaman terima kasih yang tidak sesuai dengan situasinya dapat menimbulkan kesalahpahaman, meski tidak sampai menimbulkan masalah yang berarti. Misalnya pada suatu kesempatan, penulis ditraktir oleh native speaker makan siang. Setelah selesai makan, secara spontan penulis mengatakan "Sensei, arigatou gozaimashita." Pada saat itu ia menjelaskan bahwa ungkapan 'arigatou gozaimashita' pada situasi tersebut menimbulkan kesan penulis berterima kasih bahwa berkat traktirannya tersebut, penulis dapat makan. Berbeda dengan ungkapan terima kasih ringan yang seharusnya diungkapkan pada saat menerima traktiran.
Bagi pembelajar bahasa asing, pemahaman lintas budaya diperlukan untuk meminimalisir adanya friksi bila terjadi kontak dengan orang asing dengan tujuan saling memahami dan menghargai perbedaan. Setiap budaya memiliki konsep, situasi, dan ungkapan persalaman berlainan untuk menyatakan terima kasih. Oleh karenanya penulis tertarik untuk mengkaji perbedaan antara persalaman terima kasih dalam bahasa Indonesia dan bahasa Jepang, agar dapat mengetahui konsep persalaman terima kasih pada kedua budaya, memahami situasi yang memunculkannya, dan juga mengetahui ungkapan yang digunakan untuk menyampaikan rasa terima kasih.

\section{PEMBATASAN MASALAH}

Ungkapan terima kasih merupakan persalaman standar yang tidak boleh tidak diketahui dan digunakan dalam kehidupan sehari-hari, karena dalam kehidupan bermasyarakat seseorang pasti memerlukan bantuan dari orang lain, sehingga ungkapan persalaman terima kasih perlu untuk dipahami dan diungkapkan agar terjalin hubungan yang baik dengan sesama.

Permasalahan pada penelitian ini dibatasi hanya untuk mengetahui konsep persalaman terima kasih dalam budaya Indonesia dan Jepang, memaparkan perbedaan ungkapan salam yang digunakan oleh orang Indonesia dan Jepang dalam menyampaikan rasa terima kasih sesuai dengan situasi yang melatarinya tanpa memperhitungkan jawaban yang diberikan atas ungkapan rasa terima kasih tersebut.

\section{ISI}

\subsection{Konsep Persalaman Terima Kasih dalam Bahasa Indonesia}

Bila dibandingkan dengan referensi dalam bahasa Jepang, referensi mengenai konsep persalaman terima kasih dalam bahasa Indonesia dirasakan sangat kurang dan sulit mendapatkan sebuah buku yang membahas dengan lengkap mengenai hal ini.

\subsubsection{Konsep Menerima Kebaikan}

Ungkapan persalaman terima kasih dalam bahasa Indonesia biasa diucapkan pada 
saat menerima suatu kebaikan dari orang lain. Suatu kebaikan ini dapat berupa bantuan, hadiah atau pemberian lain yang dianggap bermakna bagi penerima tersebut. Ukuran kebaikan yang diterima pun tidak dibatasi, dari hal yang kecil seperti diambilkan minum oleh teman sampai diberi hadiah besar.

\subsubsection{Konsep Yang Lain}

Ungkapan persalaman terima kasih dalam bahasa Indonesia juga diungkapkan dengan maksud yang berbeda dengan makna ungkapan persalaman terima kasih yang sebenarnya seperti yang telah disebutkan di atas. Misalnya pada situasi berikut ini,

1. bila diucapkan sambil menganggukan kepala, berarti tanda setuju

2. bila diucapkan sambil mengangkat tangan, artinya penolakan dengan sopan

3. bila diucapkan sambil marah-marah disertai dengan kata-kata yang tidak sopan berarti menyindir

\subsubsection{Perwujudan Sikap}

Ungkapan persalaman terima kasih biasanya disertai dengan ekspresi wajah yang menunjukkan ketulusan dan kesopanan kepada orang yang memberi kebaikan. Selain itu ungkapan persalaman terima kasih bisa disertai dengan gerakan berjabat tangan, anggukan kepala, dan senyuman.

\subsubsection{Bentuk Pengungkapan Rasa Terima kasih}

Bentuk ungkapan rasa terima kasih dalam kehidupan masyarakat Indonesia tidak terlalu bervariasi dalam bentuknya dan dibedakan hanya berdasarkan keformalannya.

\section{1) Menggunakan Ungkapan Persalaman Standar Yang Sudah Ada}

Ungkapan persalaman standar yang digunakan untuk mengungkapkan rasa terima kasih adalah sebagai berikut,

(1) Terima Kasih

Menurut Kamus Besar Bahasa Indonesia terima kasih berarti mengucap syukur, melahirkan rasa syukur atau membalas budi setelah menerima kebaikan dan sebagainya.Pengungkapan rasa terima kasih menggunakan kata terima kasih mempunyai variasi berikut,

a. Terima Kasih

Ungkapan persalaman dengan menggunakan kata terima kasih ini adalah bentuk ungkapan persalaman standar dalam bahasa Indonesia yang dapat diungkapkan kepada siapa saja tidak terbatas usia, jenis kelamin, kedudukan, jabatan, karakteristik masalah, dan sebagainya, dalam situasi yang formal maupun informal. Bila merasa sangat bersyukur telah menerima kebaikan yang besar dari seseorang, kata 'banyak' bisa ditambahkan setelah kata 'terima kasih' menjadi 'terima kasih banyak' .

b. Makasih

Ungkapan persalaman menggunakan kata makasih ini diungkapkan dalam situasi yang informal. Penggunaan kata makasih yang digunakan dalam mengekspresikan rasa terima kasih ini menyiratkan kedekatan hubungan antara pembicara dan lawan bicara.

c. Trims

Hampir sama dengan penggunaan ungkapan persalaman 'makasih', ungkapan rasa terima kasih menggunakan kata 'trims' ini merupakan ungkapan rasa terima kasih yang ringan dalam situasi yang informal kepada orang yang telah memiliki hubungan dekat dengan pembicara atau kepada orang yang mempunyai kedudukan di bawah pembicara.

Dalam mengungkapkan rasa terima kasih, orang Indonesia lebih menyukai menyebutkan kata 'terima kasih' secara eksplisit. Meskipun terkadang ungkapan persalaman terima kasih itu juga disertai dengan mendeskripsikan fakta seperti, "Makasih ya, sudah mau mengantar saya jalan-jalan hari ini." Atau disertai dengan mendeskripsikan perasaan pembicara seperti, "Makasih ya, saya senang kita menghabiskan waktu bersama tadi." Namun ungkapan 
persalaman terima kasih dengan hanya memperlihatkan ekspresi 'terima kasih' tanpa kata seperti dalam sinetron di televisi, sepertinya jarang dijumpai dalam kehidupan sehari-hari.

\subsection{Konsep Persalaman Terima Kasih dalam Bahasa Jepang}

Ungkapan rasa terima kasih dalam kehidupan masyarakat Jepang bukanlah sesuatu yang mudah dipahami orang asing, karena dapat diungkapkan dengan bermacammacam ekspresi. Oleh karena itu agar dapat memahami dan menggunakannya, berikut ini penulis akan memaparkan hal-hal yang berkaitan dengan hal tersebut.

\subsubsection{Konsep Beruntung dan Tidak Beruntung (Rieki to Furieki)}

Jika dirumuskan bahwa pembicara adalah A dan lawan bicara adalah B, bila A mendapatkan keuntungan dari $\mathrm{B}$, maka $\mathrm{A}$ akan berterima kasih pada B. Maka berdasarkan konsep tersebut, bisa dikatakan bahwa B menggerakkan A untuk mempunyai perasaan tertentu agar memenuhi syarat pernyataan di atas.

\subsubsection{Perwujudan Sikap (Taido)}

Orang Jepang berpendapat bahwa menunjukkan sikap membungkuk dengan sepenuh hati tanpa kata lebih efektif untuk menunjukkan rasa terima kasih, daripada menggunakan kata-kata verbal secara langsung untuk mengungkapkan rasa terima kasih.

Bagi orang Jepang, ungkapan rasa terima kasih akan lebih mengena bila diungkapkan sambil memikirkan esensi dari tindakan tersebut. Kata-kata maupun sikap yang diperlihatkan saat mengungkapkan rasa terima kasih terasa tulus bila didukung dengan perasaan jujur saat mengungkapkannya. Misalnya saat mengungkapkan rasa terima kasih dalam hati juga berjanji "tidak akan melupakan kebaikan hati lawan bicaranya".

\subsubsection{Bentuk Pengungkapan Rasa Terima kasih (Kansha no Hyougen)}

Bentuk ungkapan rasa terima kasih dalam kehidupan masyarakat Jepang ditentukan menurut situasi, hubungan antara pembicara dan lawan bicara, karakteristik masalah, derajat kedalaman masalah, jenis kelamin dan usia pembicara. Rasa terima kasih dalam bahasa Jepang dapat diungkapkan menggunakan beberapa cara, diantaranya adalah sebagai berikut,

\section{1) Menggunakan Persalaman Standar Yang Sudah Ada}

Ungkapan persalaman standar yang digunakan untuk mengungkapkan rasa terima kasih adalah sebagai berikut,

(1) Arigatou

Secara harfiah kata arigatou mengandung arti "sesuatu yang sukar". Kedalaman makna arigatou dijiwai anggapan bahwa sedapat mungkin seseorang harus mengembalikan kebaikan yang diterima dari orang lain. Mengingat sukarnya mengembalikan budi baik seseorang, mereka menyatakan kebaikan yang diterima sebagai sesatu yang sukar dibalas. Pengungkapan rasa terima kasih menggunakan kata arigatou mempunyai variasi berikut,

a. Doumo Arigatou dan Arigatou

Merupakan ungkapan rasa terima kasih yang disampaikan pembicara kepada orang yang berada pada level yang sama, baik dari segi usia, status sosial, maupun kedudukan, seperti teman dan rekan kerja, atau pada bawahan.

b. Doumo Arigatou Gozaimasu dan Doumo Arigatou Gozaimashita

Merupakan ungkapan rasa terima kasih formal yang disampaikan pembicara kepada orang yang belum dikenal dekat, orang yang mempunyai level di atas pembicara baik dari segi usia, status sosial, maupun kedudukan, seperti atasan, senior di sekolah, kampus, atau kantor.

Doumo arigatou gozaimasu dan doumo arigatou gozaimashita dapat diucapkan tanpa menyebutkan doumo.

Penambahan kata doumo pada arigatou gozaimasu dan arigatou 
gozaimashita dipakai untuk menyatakan ungkapan rasa terima kasih secara lebih mendalam. Selain dengan menambahkan kata doumo, rasa terima kasih lebih mendalam dapat pula diungkapkan dengan melekatkan kata hontouni atau makotoni di depan kata arigatou gozaimasu atau arigatou gozaimashita.

\section{c. Doumo}

Merupakan ungkapan terima kasih ringan yang disampaikan pembicara kepada orang-orang yang mengerjakan suatu pekerjaan yang sudah merupakan bagian dari tugasnya. Misalnya kepada sekretaris yang telah menyeduhkan kopi dan menuliskan notulasi rapat.

Sebagai catatan, doumo tidak digunakan kepada orang yang mempunyai level di atas pembicara.

\section{(2) Sumimasen dan suimasen}

\section{a. Sumimasen dan suimasen}

Merupakan ungkapan rasa terima kasih yang ringan. Misalnya pada saat seseorang yang usianya lebih muda menuangkan minuman untuknya pada waktu pesta, pembicara cukup mengatakan "A, sumimasen." sebagai ungkapan rasa terima kasih. Untuk situasi yang informal kata suimasen bisa digunakan sebagai gantinya.

b. Doumo sumimasen

Merupakan ungkapan bermakna ganda. Bisa berarti ungkapan rasa terima kasih atas kebaikan yang diterima atau permintaan maaf atas kerepotan yang ditimpakan pada orang lain. Misalnya pada saat seseorang memberitahukan orang yang berjalan di depannya bahwa barang miliknya jatuh, maka pemilik barang yang jatuh tersebut akan menggunakan kata "Doumo sumimasen." untuk mengucapkan terima kasih atas kebaikan orang tersebut sekaligus meminta maaf atas kesudian orang tersebut menyampaikan perhatian serta menyisakan sedikit waktu untu memberitahukan adanya barang yang jatuh. Contoh lain, pada saat anaknya diberi makanan oleh kenalannya, seorang ibu akan menggunakan kata "Doumo sumimasen." untuk mengungkapkan rasa terima kasihnya. Bila pada situasi ini sang ibu menggunakan ungkapan arigatou gozaimashita untuk mengungkapkan rasa terima kasihnya, akan timbul pengertian kalau ia memang menginginkan makanan tersebut diberikan pada anaknya.

Selain ungkapan yang telah disebutkan di atas, ada beberapa ungkapan persalaman standar yang biasa digunakan untuk berterima kasih seperti,

(3) Osore irimasu, merupakan ungkapan rasa terima kasih yang sopan. Misalnya untuk situasi yang sama dengan (2a) di atas, kepada orang yang usianya lebih muda yang menuangkan minuman untuknya pada waktu pesta, ada pula pembicara (perempuan) dengan tutur kata halus menggunakan kata "Osore irimasu." atau "Arigatou gozaimasu." untuk mengungkapkan rasa terima kasih.

(4) Gochisousama (deshita) merupakan ekspresi yang digunakan untuk mengungkapkan rasa terima kasih setelah menerima kebaikan ditraktir oleh seseorang.

(5) Gokurousama digunakan untuk mengungkapkan rasa terima kasih kepada bawahan yang telah bekerja dengan giat.

(6) Okagesamasade merupakan jawaban atas sapaan seseorang yang menanyakan kabar pembicara, dalam ekspresi ini terkandung ungkapan terima kasih atas perhatian yang diberikan.

Bila pembicara merasa senang karena mendapatkan keuntungan atau menerima kebaikan / jasa dari lawan bicaranya, maka akan dipilih ungkapan arigatou gozaimasu daripada sumimasen. Misalnya pada saat menerima hadiah ulang tahun seseorang akan 
mengatakan arigatou gozaimasu sebagai ungkapan rasa terima kasih.

Dalam budaya masyarakat Jepang, seseorang yang tidak tahu berterima kasih diidentikkan dengan orang yang tidak bisa menghargai kebaikan orang lain dan tidak beradat. Bantuan atau jasa yang diterima dari seseorang harus diingat, setidak-tidaknya sampai bertemu lagi dengan pemberi. Biasanya pada waktu bertemu kembali dengan pemberi bantuan atau jasa setelah menerima kebaikan, penerima kebaikan perlu mengungkapkan rasa terima kasihnya kembali disertai pujian betapa pentingnya bantuan tersebut atau betapa bagusnya barang yang diterima. Dengan demikian pemberi akan merasa dihargai dan mendapatkan pesan bahwa apa yang telah diberikannya bermanfaat.

\section{2) Mendeskripsikan Fakta}

Merupakan cara pembicara mengungkapkan rasa terima kasih pada lawan bicara tanpa menggunakan ungkapan persalaman standar yang ada, tetapi dengan menyebutkan keuntungan/jasa yang diperolehnya. Misalnya pada situasi-situasi berikut ini,

(1) Setelah menerima pengajaran mengenai bermacam-macam hal dari seseorang, akan diungkapkan rasa terima kasih seperti ini, "Saki datte wa iroiro gokyouji itadakimashite..." <Terima kasih telah mengajari saya bermacam-macam hal....>, kalimat tersebut bisa diikuti dengan "arigatou gozaimashita" <terima kasih> maupun tidak, karena dengan kalimat yang belum selesai seperti contoh di atas, lawan bicara telah mengerti bahwa pembicara sedang mengungkapkan rasa terima kasihnya.

(2) Setelah selalu menerima bantuan terus menerus dalam waktu yang lama "Hontouni nagai aida, nani kara nani made osewa ni narimashita" <Terima kasih telah selalu membantu saya dalam waktu yang lama dari a sampai z.>, ungkapan ini biasanya diucapkan pada saat perpisahan.

(3) Atas dukungan yang diperoleh sehingga mencapai keberhasilan "Anata no okageyo" < Ini berkat anda.>
Tanpa mengucapkan terima kasih secara eksplisit pun, telah dipahami bersama oleh masyarakat Jepang bahwa ungkapanungkapan seperti contoh di atas merupakan ungkapan rasa terima kasih.

Karena ungkapan di atas bukan merupakan ungkapan persalaman standar yang biasanya digunakan untuk mengucapkan terma kasih, nada suara, ekspresi wajah, dan gesture menjadi penting, bila tidak diekspresikan dengan tepat bisa menimbulkan kesalahpahaman.

\section{3) Mendeskripsikan Perasaan Pembicara}

Merupakan cara pembicara mengungkapkan rasa terima kasih pada lawan bicara tanpa menggunakan ungkapan persalaman standar yang ada, tetapi menggunakan pernyataan rasa senang dan rasa terima kasih pembicara atas keuntungan atau bantuan yang diperolehnya. Misalnya pada situasi berikut ini, dalam sebuah adegan drama seri Jepang digambarkan suami yang baru pulang kerja menghampiri istrinya, yang telah menanti kepulangannya dan menyiapkan air panas untuk mandi, seolah berbicara pada dirinya sendiri ia berkata, "Arigataina" $<$ Rasanya ingin berterima kasih ya.>, hal ini sudah cukup mengungkapkan rasa terima kasihnya. Setelah itu, masih merupakan kelanjutan cerita tadi, setelah selesai berendam air panas, sang suami menghampiri istrinya yang berada di dapur dan berkata, " $I i$ kimochidayo" <Rasanya nyaman sekali.> yang juga merupakan ungkapan rasa terima kasihnya.

\section{4) UngkapanTanpa Kata-Kata}

Ungkapan terima kasih tanpa katakata ini bisa dikatakan sebagai ungkapan penghilangan atau pemendekan ungkapan terima kasih. Penekanannya adalah bahwa ungkapan rasa terima kasih tersebut tidak keluar menjadi sebuah ujaran bermakna disebabkan oleh perasaan gembira yang meluap dari awal atau pertengahan ujaran. Meskipun tidak dilukiskan dengan kata-kata, tetapi sebagai sebuah ekspresi rasa terima kasih, hal ini tidak bisa diabaikan. Bahkan bila dibandingkan dengan variasi ungkapan rasa terima kasih yang lain terkadang jauh 
lebih mengena. Misalnya pada situasi berikut ini, pada sebuah adegan drama seri Jepang, digambarkan anak perempuan yang pada awalnya tidak diijinkan menikah oleh ayahnya, tidak dapat berkata-kata setelah sang ayah akhirnya merestui pernikahannya, ia hanya dapat berkata "Otousan...." $<$ Ayah...> untuk mengungkapkan rasa terima kasihnya.

\subsection{Perbandingan Konsep Persalaman Terima Kasih dalam Bahasa Indonesia dan Bahasa Jepang}

Konsep persalaman terima kasih dalam bahasa Indonesia adalah rasa syukur setelah menerima suatu kebaikan dari orang lain, sedangkan konsep persalaman terima kasih dalam bahasa Jepang adalah rasa beruntung yang dirasakan sebagai hasil perbuatan orang lain. Di samping itu, persalaman terima kasih dalam bahasa Indonesia dalam situasi tertentu dapat mengandung pernyataan lain seperti persetujuan, penolakan sopan, dan sindiran bila disertai dengan gerakan atau ungkapan yang lain.

Sikap yang menyertai ungkapan rasa terima kasih dalam bahasa Indonesia adalah ekspresi wajah yang menunjukkan ketulusan yang ditujukan kepada orang yang memberi kebaikan, dapat pula disertai dengan gerakan jabat tangan, anggukan kepala, dan atau senyuman. Sedangkan sikap yang menyertai persalaman sebagai perwujudan rasa terima kasih dalam bahasa Jepang adalah perasaan jujur dan tulus pada saat mengungkapkannya. Dalam budaya Jepang sikap membungkuk tanpa kata-kata dikatakan lebih efektif digunakan untuk mengungkapkan rasa terima kasih daripada kata-kata.

Dalam pengungkapan persalaman terima kasih, bahasa Indonesia tidak terlalu beragam. Variasi ungkapan persalaman standar yang digunakan hanya ada tiga yaitu 'terima kasih', 'makasih', dan 'trims' untuk segala situasi penerimaan kebaikan. Yang perlu diperhatikan adalah segi keformalan situasi pada saat mengungkapkan persalaman terima kasih itu. Kata 'terima kasih' digunakan dalam situasi yang formal dan informal, sedangkan kata 'makasih' dan 'trims' digunakan pada situasi yang informal kepada orang yang mempunyai hubungan akrab. Orang Indonesia lebih menyukai pengungkapan rasa terima kasih secara eksplisit, meskipun terkadang disertai pula dengan pendeskripsian fakta yang telah terjadi dan perasaan pembicara. Boleh dikatakan bahwa kata 'terima kasih' sebagai ungkapan persalaman terima kasih yang bersifat netral karena dapat dikatakan pada segala situasi baik formal maupun informal kepada siapa saja tanpa kecuali.

Sementara itu pengungkapan persalaman dalam bahasa Jepang sangat beragam baik dari segi situasi maupun ungkapan persalaman standar yang digunakan. Persalaman terima kasih dalam bahasa Jepang diungkapkan menggunakan ungkapan persalaman standar yang ada, mendeskripsikan fakta pada situasi tertentu, mendeskripsikan perasaan pada situasi tertentu, dan pengungkapan ekspresi tanpa kata-kata. Ungkapan persalaman standar yang digunakan dalam menyampaikan rasa terima kasih di Jepang ada enam buah, yaitu (1) 'arigatou' dengan variasi 'arigatou' dan 'doumo arigatou' yang digunakan kepada orang yang berada dalam level yang sama baik dari segi usia, status sosial, maupun kedudukan; 'doumo arigatou gozaimasu' yang digunakan untuk mengungkapkan rasa terima kasih atas sesuatu yang selalu diberikan dan yang belum diterima sepenuhnya dan 'doumo arigatou gozaimashita' yang merupakan ungkapan rasa terima kasih untuk sesuatu yang telah diterima; 'doumo' yang merupakan ungkapan terima kasih ringan, (2) sumimasen dan suimasen yang merupakan ungkapan rasa terima kasih yang ringan; doumo sumimasen yang merupakan ungkapan bermakna ganda. Bisa berarti ungkapan rasa terima kasih atas kebaikan yang diterima atau permintaan maaf atas kerepotan yang ditimpakan pada orang lain; (3) osore irimasu, merupakan ungkapan rasa terima kasih yang sopan; (4) gochisousama (deshita) yang merupakan ekspresi yang digunakan untuk mengungkapkan rasa terima kasih setelah menerima kebaikan ditraktir oleh seseorang; (5) gokurousama merupakan ekspresi yang digunakan untuk mengungkapkan rasa terima kasih kepada 
bawahan yang telah bekerja dengan giat; dan (6) okagesamasade yang merupakan jawaban atas sapaan seseorang yang menanyakan kabar

Pengungkapan persalaman terima kasih dalam bahasa Indonesia biasanya cukup diucapkan sekali pada saat menerima kebaikan, namun dalam bahasa Jepang pengungkapan persalaman terima kasih ada kalanya perlu diungkapkan kembali saat bertemu lagi setelah menerima kebaikan untuk menyatakan penghargaan.

\section{SIMPULAN}

Bila dibandingkan dengan budaya Indonesia, pengungkapan rasa terima kasih dalam budaya Jepang lebih beragam dari segi situasi maupun ungkapan persalaman standar yang ada. Oleh karena itu pembelajar bahasa Jepang dari Indonesia perlu berhati-hati saat memilih ungkapan persalaman terima kasih yang ada.

Dilihat dari konsepnya dalam bahasa Indonesia terdapat konsep rasa syukur menerima kebaikan sedangkan dalam bahasa Jepang terdapat konsep rasa beruntung menerima kebaikan.

Untuk sikap, orang Indonesia menyertai ungkapan persalaman terima kasih tengan sikap tulus dan sopan dengan gerakan mengangguk, berjabat tangan atau senyuman, sedangkan kebanyakan orang Jepang lebih memilih untuk mewujudkan rasa terima kasihnya lewat sikap membungkuk pada lawan bicara dengan sepenuh hati daripada mengungkapkan kata-kata.

Ungkapan rasa terima kasih dalam budaya Indonesia kebanyakan diungkapkan dengan mengucapkan 'terima kasih'secara eksplist, sedangkan budaya Jepang dapat dilakukan dengan empat cara, yaitu menggunakan ungkapan persalaman standar yang sudah ada, mendeskripsikan fakta, mendeskripsikan perasaan pembicara, ekspresi yang bukan berupa kata-kata.

Pilihan ungkapan rasa terima kasih dalam bahasa Jepang perlu disampaikan disesuaikan situasi, hubungan antara pembicara dan lawan bicara, karakteristik masalah, derajat kedalaman masalah, jenis kelamin dan usia pembicara, tidak seperti pengungkapan persalaman terima kasih dalam bahasa Indonesia yang hanya perlu mempertimbangkan segi keformalan saja.

Pengungkapan persalaman terima kasih dalam bahasa Indonesia cukup diucapkan sekali pada saat menerima kebaikan, sedangkan dalam bahasa Jepang pengungkapan persalaman terima kasih perlu diungkapkan kembali saat bertemu.

\section{DAFTAR PUSTAKA}

Edizal. 2001. Tutur Kata Manusia Jepang : Nihonjin No Mono Ni Iikata. Kayu Pasak : Padang

Mizutani, Osamu. 1979. Nihongono Seitai : Hanashi Kotoba To Nihonjin. Ontaimu : Tokyo. 1983. Nihongo No Hyougen : Hanashi Kotoba No Hyougen. Chikuma Shobou : Tokyo.

Sano, Masayuki dkk. 1995. Ibunka Rikai No Sutoratejii. Tokyo : Taishuukan Shoten

Shimazaki Youichi dkk. 1999. Japanese Dictionary: Info Word Kokugo Jiten. Benesse : Tokyo.

\section{Rujukan Elektronik :}

http://www.antaranews.com/berita/1271201980/kekuatan-ucapan-terima-kasih (18.012011)

http://pusatbahasa.diknas.go.id/kbbi/index.php (20.01.2011)

//id.wikipedia.org (18.01.2011) 